\title{
Small Intestinal Serosal Surface
}

National Cancer Institute

\section{Source}

National Cancer Institute. Small Intestinal Serosal Surface. NCI Thesaurus. Code C33571.

The thin outermost layer of loose connective tissue covering the outer surface of the small intestine. It is derived from the peritoneum. 